\title{
The rule of force: militarism and the militarization of politics in the early Brazilian Republic (1889-1890) ${ }^{1}$
}

\author{
Filipe Nicoletti Ribeiro
}

\begin{abstract}
This article addresses the immediate aftermath of the November 15, 1889, republican coup d'état in Brazil. Taken into account the diversity of the states' political landscapes, its main theme is the profound transformation in the country's political life precipitated by the abrupt passage from a parliamentary monarchy, marked by the ascendancy of civilian institutions, to a military dictatorship. it will be shown that, given the fact that republicans were a fragmented minority in most of the country, the military had preeminence in the implementation of the regime. However, considering that the coup was itself an act of insubordination, that control over institutions created frictions, and that the role of arbiters contaminated the barracks with the period's extreme polarization, the liabilities of the militarization of politics were soon manifest. They were, most notably, the deep unrest and factionalism in the armed forces, the continuous institutional degradation, and the rise of authoritarianism.
\end{abstract}

\footnotetext{
${ }^{1}$ This article draws from chapters 4 and 5 of my doctoral thesis, Da monarquia parlamentar ao regime da ordem: tensões partidárias, conflitos políticos e a ascensão do militarismo na passagem do Império para a República (1880-1891). I would like to thank the Coordenação de Aperfeiçoamento de Pessoal de Nível Superior (CAPES) for the grant that enabled the research.
} 
In its first edition following the coup d'état of November 15, 1889, which overthrew the Brazilian Empire, The Rio News, a newspaper published in the country's capital by an American expatriate, declared that never had such a far-reaching "revolution" been "effected so pacifically!" The assertion seemed premature, however. In that same edition, alongside the publication of the first decrees of the provisional government headed by Marshal Manuel Deodoro da Fonseca, the leader of the uprising, and of news concerning the exile of the imperial family and the imprisonment of former ministers and allies of the ousted Liberal cabinet, there were signs of discontent. One article mentioned that the republican "revolution" was causing "radical changes in the army," and that officers "favored by the monarchy" or who had not "committed themselves to the new movement" had been "removed". Another report declared that a "military force" had occupied the telegraph office, restricting the circulation of messages, especially those of a political nature. Yet another mentioned the arrest of seamen "for cheering for the monarchy" and attacking army "sentinels." 2

In the following edition, newspaper articles took a somewhat alarming tone. Although indicating that the "interested control of the revolutionary authorities" over "all telegraphic information" meant that the press had to filter hearsay from multiple sources, The Rio News could not ignore signs of disturbances in the "course of revolutionary events." Thus, the newspaper mentioned an "apparent hesitation" or "threatened opposition" to the new regime in some states, and "countless rumors of secret military executions of insubordinate sailors and marines," but could not attest to the veracity of such rumors. ${ }^{3}$

It is important to consider that the unexpected news of the coup reached much of the country when the republic was already a fait accompli in Rio de Janeiro. This meant that news from the capital, circulating through official filters, had a direct influence on how events developed elsewhere. Therefore, the overthrow of imperial institutions by a sector of the armed forces, aided by a portion of the civilian elite, was roughly reproduced at the state level, but with wide variations akin to the prevailing balance of power, as well as to the scope of military presence in each state.

Thus, over the subsequent weeks, news of military unrest and revolts against the republic throughout the country would inevitably circulate. Ten months after the insurgents celebrated their peaceful "revolution," effected by the army and navy in "perfect communion of sentiments with our fellow citizens in the provinces," the correspondent of a Bahian newspaper would add to the somber picture the explosive tensions between the two forces. Remarking that the "powerful cannons" of

${ }^{2}$ The Rio News. Nov. 18, 1889.

${ }^{3}$ The Rio News. Nov. 25, 1889. 
the navy's battleships could soon be aimed against the government, he added that "[e]verything is possible," since "brute force sovereignly rules." 4

Hence, the idea of a bloodless republican "revolution" (or "proclamation"), in which it is implied that the November coup d'état was a somewhat natural development in Brazil's political evolution, is problematic. This idea seems, in fact, to be at the root of the perplexing "historiographical gap" around the 1889 transformative event, highlighted by Frank McCann (2009, p. 28). Moreover, historians tend to overlook the coup's immediate aftermath, paying little attention to the provisional government's legislative and administrative records and its far-reaching efforts to liquidate imperial institutions (Cardoso, 1975; Carone, 1983). Both gaps can be explained as consequences of historical-methodological approaches that characterize the Empire's institutional edifice as a "fiction" sustained by the Crown's unlimited reach and intervention in all aspects of political life (Holanda, 1977; Carvalho, 2003), or as a colonial residue, consubstantiated with slavery and condemned by its crisis (Costa, 1985; Mattos, 1987).

In both cases, the overthrow of imperial institutions lacks historical meaning, being more or less easily explained as a death by natural causes, or as the logical consequence of a "progressive" historical process. It is problematic enough that these postulations were embraced by several contemporaries in order to legitimize their own participation in the coup, or to justify their failure in preventing it (Campos Sales, 1983; Vianna, 1896). There is, however, at least another concerning implication in such propositions: if man-made institutions are empty vessels that lack historicity, the ideas and actions of the men and women who shape them (even in their struggle to resist them) lose meaning (Arendt, 1961).

Recently, scholars have been paying closer attention to the Empire's complex political and institutional framework and pointing out to the growing permeability of the imperial state, in its final decades, to the demands of an expanding public sphere (Dolhnikoff, 2005; Graham, 2011; Dantas, 2011; Ferraz, 2012; Ribeiro, 2015; Lynch, 2018). It is therefore my argument here that not only do the full implications of the November coup d'état have to be scrutinized against this background, but that the vicissitudes of the Brazilian First Republic cannot be fully explained without prior scrutiny of the concentrated effort, in its early moments, to demolish the Empire's political and institutional edifice. Primordial to this effort was the subversion of a previous consensus regarding the supremacy of civilian rule (and therefore the rule of law) by the ascension of a military dictatorship. The growing insubordination, indiscipline, and factionalism in the barracks and the overall arbitrariness engendered by the militarization of politics were fundamental elements of the

\footnotetext{
${ }^{4}$ Pequeno Jornal. Sept. 2, 1890.
} 
regime installed in 1889, having among their long-term effects the reversal of the aforementioned trend of expansion of the public sphere. To better understand this profound shift in the country's political life I will rely largely on the fragments offered by primary sources.

\section{Hierarchy and insubordination}

In letters addressed, in the year of 1890, to former leaders of the Liberal Party, the Viscount of Pelotas decried the events of November 15, declaring that the sad state of the country in the previous months was due to the fact that the republic had been the result of a "pronunciamento" supported by only "one fifth of the army," a portion of the garrison then stationed in Rio de Janeiro (Holanda, 1977, p. 341). Himself a former Liberal senator, Pelotas's assertions could be interpreted as partisan rancor, since the Liberal Party was in power when the monarchy fell and suffered the bulk of its defeat. But Pelotas was also a senior military officer and, as lieutenant general, ${ }^{5}$ was in fact above Deodoro da Fonseca, a field marshal, in the army's hierarchy at the time of the coup (Magalhães Júnior, 1957, p. 188, v. 1). Moreover, following the upheaval, Pelotas was appointed as the first governor of his state, Rio Grande do Sul, by the provisional government. The viscount justified the acceptance of this commission as a patriotic duty vis-à-vis the threat of disorder and even "civil war" in the wake of the coup. Both this assertion and the one attributing the establishment of the new order by a fraction of the army deserve further consideration.

Historians have already indicated that, on the eve of November 15, the army's upper echelons remained broadly loyal to imperial institutions, and that sympathies for republican ideas were mainly concentrated among younger officers still distant from the peak of their careers (Carvalho, 2005, pp. 38-39; Lynch, 2018, pp. 207-209). In the Clube Militar, an organization born in the late 1880s out of a diffuse dissatisfaction with the conduct of military affairs (and at some level, of all affairs) by the casacas, the civilian political elite trained in a much-maligned parliamentary tradition, senior officers were scarce. In fact, once the turmoil caused by the 1886-87 "military question"6 - which prompted the creation of the Clube as a sort of pressure group for the advancement of corporate interests - dwindled, the organization was deserted by most of its founders, including Pelotas, and

\footnotetext{
5 Jornal do Recife. Jan. 11, 1890.

${ }^{6}$ The "questão militar" was a series of conflicts involving the Conservative cabinet headed by the Baron of Cotegipe and some army officers. Fruit of disagreements regarding the rights of officers to publish opinion pieces on the press, the issue soon became a source of political controversy particularly heated in the capital and in Rio Grande do Sul, where Deodoro da Fonseca held command over the garrison and was appointed provincial president. Put against the wall, the marshal chose to support the claims of his fellow officers, countering the authority of the civilian government on the issue and in the process destroying his political prospects as a lifelong member of the Conservative Party (Magalhães Júnior, 1957, v. 1; Castro, 1995).
} 
was soon dominated by the more radicalized (especially junior) officers, and became the breeding ground for the conspiracy that would overthrow the monarchy (Castro, 1995, pp. 126-128, 154).

This made the president of the Clube Militar, Deodoro da Fonseca - whose political and military careers were stalled after the breakup of his lifelong affiliation to the Conservative Party, following his participation in the "military question" -, the most senior army officer actively involved in the seditious ploy and thus indispensable to a movement that sought legitimacy as a vessel for the armed forces' grievances (Castro, 1995, pp. 162-164). Deodoro's relevance was accentuated by the fact that the most senior co-conspirator in the navy, Eduardo Wandenkolk, was further away from the top of the force's hierarchy, as a chefe de divisão, a rank equivalent to the army's brigadier (Magalhães Júnior, 1957, p. 88, v. 2). Moreover, navy officers seemed to be broadly loyal to the Empire (and mostly Liberal), what made Wandenkolk's relative isolation more pronounced (Castro, 1995, p. 97; Arias Neto, 2001, p. 132).

Therefore, the November 15 coup was not simply the fruit of a sedition of discontented officers against a lawful civilian government; it was an act of military insubordination (McCann, pp. 36-37). It is important to remember that the war and navy ministers in the Liberal cabinet headed by the Viscount of Ouro Preto (June-November 1889) were military officers, respectively Field Marshal Viscount of Maracaju and chefe de divisão Baron of Ladário, who was gravely wounded by gunfire while trying to preserve the government's authority in face of the uprising. Once control of the government was secured, the dismissal of both generals gave way to the nomination of two members of the Clube Militar, Lieutenant Colonel Benjamin Constant Botelho de Magalhães (Ministry of War) and the aforementioned Wandenkolk (Navy). Furthermore, among the provisional government's first acts were the removals of several officers from positions of command and posts in the military bureaucracy, replacing them with allies of the insurgents (Magalhães Júnior, 1957, pp. 56-83, v. 2). ${ }^{7}$

The trend was followed elsewhere. In Pará, once the news arrived, junior officers of the army units stationed in the capital started discussing the deposition of the provincial president and, if necessary, the imprisonment of the senior military commander in the state, Brigadier José Ângelo de Morais Rego. Under the command of a captain, artillery pieces were disposed around the presidential palace and both the president and the commander of the garrison had to abandon their posts. In the wake of their success, the victorious officers formed a military club, ostracizing those suspected of monarchical or Liberal sympathies, including Morais Rego, who was dismissed of other

\footnotetext{
${ }^{7}$ Diario da Bahia. Nov. 21, 1889;
} 
important commissions. Parallel to this, the junta that assumed power unilaterally promoted to the ranks of officers soldiers and cadets considered to have contributed to the movement's triumph. ${ }^{8}$

The case of Ceará, a more militarized state, due to the existence of a military school in its capital, is also indictative. Following the upheaval in Rio de Janeiro, the provincial president, an army colonel, was deposed on the initiative of a group of officers led by a major. Subsequently, the commander of the infantry battalion stationed in the state, Lieutenant Colonel Luís Antônio Ferraz, was "acclaimed" governor. Ferraz soon created a secretariat, composed of the officers responsible for his ascension, alongside some civilians. ${ }^{9}$ In the interior of the northern state, periodically affected by droughts, Ferraz promptly replaced the former relief commissions with the permanent service of public assistance headed, in many municipalities, by junior officers, with generous remuneration. ${ }^{10}$

The national provisional government sanctioned this kind of arrangement. By a decree ratified on the 21 November 21, officers were authorized to remain on active duty (and thus up for regular promotions) while occupying civilian functions. ${ }^{11}$ A later decree complemented this already generous provision by allowing officers to receive compensations from bureaucratic positions in addition to their regular pay, that, in other decrees, was significantly increased. ${ }^{12}$ This prodigality was accompanied by fast promotions and a rapid expansion of the regular forces, particularly of the army.

In the weeks following the coup, there were profound changes at the top of the forces' hierarchies. Senior officers, alongside the deposed war and navy ministers, were forcefully retired or put on "half-pay" (reserva). ${ }^{13}$ Among them were Maracaju's brother, the Brigadier Baron of Rio Apa (who simultaneously held the command of army brigade and of the capital's National Guard), the Marshal of the Army Marquis of Gávea, the Lieutenant General Viscount of Penha, and the Admiral Marquis of Tamandaré. As a newspaper from São Paulo commented, it was necessary to liberate the higher ranks in order to guarantee rewards to those who had contributed to the coup's success. ${ }^{14}$

Between November 1889 and the first months of 1890, members of the provisional government and others close to them quickly escalated the military hierarchy. Field Marshal Deodoro da Fonseca rose directly to the rank of marshal of the army, skipping that of lieutenant general, being

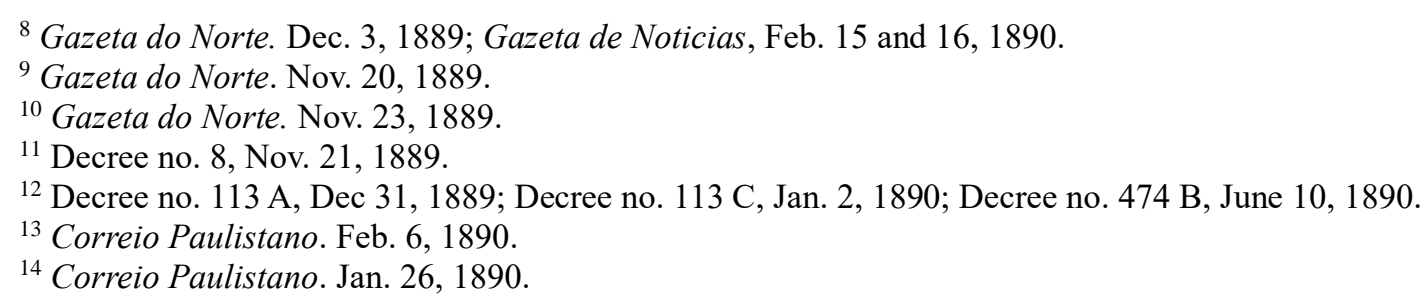


"acclaimed" generalissimo (an exclusive "rank" until then inexistent), while Lt. Col. Benjamin Constant rose successively to colonel and brigadier, and chefe de divisão Wandenkolk became, after just two months, vice admiral (Magalhães Júnior, 1957, pp. 135-136, v. 2). Deodoro's brother, Field Marshal Hermes da Fonseca (commander of the Bahia garrison), was promoted to lieutenant general, while Constant's brother, Marciano de Magalhães, gained the command of a key fortress and meteorically rose from major to colonel. ${ }^{15}$ Members of the Clube Militar and enablers of the coup were also rewarded. Among them, Brigadier José Simeão de Oliveira (nominated governor of Pernambuco), who rose to field marshal, and Field Marshal Floriano Peixoto, the adjutant-general of the army who, to say the least, neglected his duties and was compensated by keeping his post, while being promoted to lieutenant general (Magalhães Júnior, 1957, pp. 363-364, v. 2). ${ }^{16}$

The trend was reinforced by the almost doubling of the size of the army, according to a decree of December 14, and the equivalent increase in the officer corps, accompanied by the expansion of the $1^{\text {st }}$ class of the army's general staff, and of the personal staffs of the generalissimo and the military ministers. ${ }^{17}$ So extensive was the government's generosity that even the civilian ministers were promoted to the rank of brigadier generals, after a sweeping reform in the hierarchy, in May (McCann, 2009, p. 47). ${ }^{18}$

However, if the purges in the ranks were necessary to the success of a movement that lacked support in the higher ranks of both forces, they would prove hard discipline. The gradual rise, since the Paraguayan War (1864-1870), of an esprit de corps, the tributary of a professionalization of military careers (Dudley, 1976; Schulz, 1994; Costa, 1996), was interrupted on November 15, and, in the subsequent months, jealousies risen from the control over the state apparatus would grow uncontrollably (Castro, 1995, pp. 196-197). Thus, reasons for the many concessions, despite some being longstanding demands from officers, can also be found in the need to appease opposition. This was notorious in the case of the praças de pré. The fact that the third decree of the provisional government, enacted on November 16, was exclusively dedicated to reducing the duration of the service of praças in the navy, abolishing corporal punishment, and generously raising the wages of both forces' praças in the subsequent weeks, are suggestive. ${ }^{19}$

Efforts to appease were probably linked to the aforementioned articles that discussed seamen cheering for the emperor and his family following the events of November 15, which was not an

\footnotetext{
${ }^{15}$ Diario da Bahia. Nov. 22, 1889; Novidades. Jan. 22, 1890.

${ }^{16}$ Correio Paulistano. Feb. 1, 1890.

${ }^{17}$ Decree no. 56, Dec. 14, 1890; Decree no. 118 A, Jan. 4, 1890.

${ }^{18}$ A Federação. May 7, 1890; The Rio News. May 26, 1890.

${ }^{19}$ Decree no. 3, Nov. 16, 1889; Decree no. 43, Dec. 7, 1889; Decree no. 74 A, Dec. 20, 1889. The term praça de pré, or simply praça, generically referred to soldiers (soldados rasos) and non-commissioned officers (corporals and sergeants).
} 
isolated case. In the accounts of both contemporary witnesses and later historians it is commonly suggested that praças of both forces were oblivious to the real intentions of the movement led by Deodoro da Fonseca, and that many of them merely followed the lead of their commanding officers (Castro, 2004, p. 347). When the monarch's deposition became a fait accompli, the grim irony of the use of a soldier's subordination to his superiors as a tool of subversion - i.e., the use of military hierarchy for the attainment of political ends - must not have escaped many of theose involved. Apart from the profound politicization of their authority, the seditious officers must have been keenly aware of the probability that their example of insubordination would be followed by soldiers and other officers.

The Viscount of Pelotas was thus not far from the truth in his justifications for accepting the governorship of Rio Grande do Sul. Not only was the country's southernmost state its most militarized but the Liberal Party, under the leadership of senator Gaspar Silveira Martins, had built a quasi-hegemony there over the preceding years, having considerable influence over the garrisons located in the Platine frontier (Love, 1971, pp. 24-25; Vargas, 2007). More than anywhere else, unrest among officers and the thousands of troops stationed in the state could become a threat to national stability and even unity. The presence of one of the country's top generals, who also happened to be a former Liberal senator and war minister, as its governor could be crucial to the early consolidation of the republic, guaranteeing a modicum of order and avoiding a "civil war."

Indeed, in the first months of the republic, the cases of infighting between soldiers and sailors, sometimes with the participation of officers, and their skirmishes with police patrols, although far from unprecedented, became extraordinarily recurrent (and violent). Accounts of attacks on policemen and even police stations, notes on multiple cases of robbery and harassment of civilians, as well as widespread defiance of orders from superiors became commonplace in Rio Grande do Sul and elsewhere. In Uruguaiana, close to the Uruguayan border, soldiers of an infantry battalion broke into the armory, robbing weapons and ammunitions, and later raided civilians. In another municipality of the state, dozens of soldiers, led by a sergeant, mutinied and looted shops, prompting hundreds of civilians to arm themselves in order to expel them. In the booming port city of Santos, in the state of São Paulo, the constant harassment of newly-arrived immigrants by a cavalry regiment became so intolerable that "civilians got together a force of some 400," barricaded themselves, "and finally drove the soldiers into their barracks." 20

In a ministerial meeting in March, Deodoro bitterly denounced the state of "anarchy" in the ranks of the army, reproaching the minister of war, Benjamin Constant, and declaring that the army's

${ }^{20}$ Pacotilha. Dec. 12, 1889; The Rio News. Dec. 23, 1889; Aug. 4 and 11, 1890; Oct. 27, 1890. 
dissolution would be preferable to its demoralization (Abranches, 1998, pp. 140-141). Attempts to reorganize the army, dispersing its most unruly elements and imposing strict discipline, seem to have been to no avail. The police's incapacity to repress disruptive elements of the armed forces, alongside the increase in the number of praças, many recently recruited (mostly by impressment), left the government few other options than to employ men from the military to police other men from the military. One example was the increase of cavalry patrols "to prevent the fights between soldiers, sailors and policemen" in Rio de Janeiro. ${ }^{21}$ In the navy, partial solutions were tested by reimposing corporal punishment and strictly limiting the circulation of sailors, concealing them, even during most of their free time, to ships (Morgan, 2003, pp. 36-37).22

However, the continuous deployment of active personnel to police the streets, apart from the divisions it was bound to trigger in the forces, contributed to generate even more indiscipline, thus creating a vicious circle in which growing military presence created the need for more military presence. It also sent the message that members of the armed forces were exempt from following the rules imposed on other sectors of society. The irony was evident: "the police must mind only civilian law-breakers." 23

Thus, the regime found itself in a conundrum. It had to impose order and discipline on the (growing) troops, while continuing a policy of purges to open the ranks to its allies, thus securing the military as a trustworthy power base. In other words, the deep politicization of the armed forces was an inevitable and continuous consequence of the military takeover of state institutions. Despite the efforts to attribute the disorderly conduct of soldiers - recruited from the "lowest elements" of society - to widespread "drunkenness" and to alleged "natural" inclinations to indiscipline, the contrast between the reluctant responses to many episodes of indiscipline and, as we shall see, the drastic reactions to others is indicative that the government was aware of the political nature of much of what was deemed as mere indiscipline.

\section{Law and lawlessness}

In order to examine the interweaving of the provisional government's insecurities, the rise of authoritarianism, and the militarization of politics, I will once again resort to the situation across the country's states. Conflicting news of the coup d'état first reached the capital of Maranhão on November 16, creating a climate of uncertainty. The loose republican movement in the northern state had grown after the abolition of slavery, on May 13, 1888, but still represented a tiny minority

${ }^{21}$ The Rio News. Feb. 17, 1890.

${ }^{22}$ Diario de Noticias. Aug. 12, 1890.

${ }^{23}$ The Rio News. Feb. 17, 1890. 
centered around certain newspapers. Despite their small numbers, part of the republican leadership tried to rapidly oust the provincial president and assume control of the government. However, they needed military assistance to accomplish such a swift takeover of power.

Apart from the relatively reduced military presence, an early obstacle to the republicans' ambitions was the hesitation of the officers stationed in Maranhão, given the inconclusive nature of the news initially received from Rio de Janeiro. The situation was complicated by the arrival of a telegram dispatched from the capital of the key state of Bahia, in which Marshal Hermes da Fonseca urged the northern states to protect the sworn institutions. Only when Fonseca realized that the seditious movement was headed by his own brother did he reverse course, defending the acceptance of the fait accompli. The news of the formation of a national provisional government led the officers in Maranhão to take more decisive action.

In the meantime, however, growing uneasiness among the populace, broadly loyal to imperial institutions, produced a violent outcome. The republicans' haste to assume power prompted a fierce reaction that exploded on November 17, when thousands of civilians tried to attack the headquarters of Maranhão's leading republican newspaper. The withdrawal of police forces meant that the movement's suppression rested with the small army garrison, which endured a crisis of leadership. Faced with the commanding officers' hesitations, some troops opened fire against the protesters, killing and wounding dozens. The massacre (and the deflection of responsibilities) contributed to compromise the military with the republican "order," and a junta composed of officers and civilians took over government on November 18. In order to quell the opposition, the junta resorted to such draconian measures - from imprisonment to outright torture and murder - that in December the provisional government replaced it with a direct delegate whose mission was to reverse its policies (Gato, 2020).

Although apparently less extreme, the situation in Bahia - where republicanism was also insignificant - also became dramatic. The strength of Liberals, in control of the Provincial Assembly and of Salvador's municipal council, and the initial vacillation of Hermes da Fonseca, led to a deadlock that lasted for some days, during which the Liberal leadership refused to recognize the republic. The standoff seems to have emboldened popular opposition to the coup, and there were conflicting notes on multitudes of civilians marching to occupy the president's palace and organize resistance. The army's intervention was essential to crush the revolt, leaving an undetermined number of casualties. The fears of growing violence and the moderation promised by Hermes da 
Fonseca encouraged Liberal leaders, after a meeting on November 19, to compromise, thus thwarting any hopes for a successful opposition (Aragão, 1923, pp. 4-6). ${ }^{24}$

The similarities between the cases of Maranhão and Bahia are instructive, despite the obvious nuances. One important similarity was the major presence of libertos (freedmen) in popular movements. Both Maranhão and the Recôncavo - the sugar planting area surrounding Bahia's capital - had large enslaved populations until abolition, and support for the monarchy seems to have been as strong among freed people as it was a diffuse belief that the republic (which had among its main stalwarts disgruntled former slaveowners from the South) was destined to re-enslave those freed in the previous year, and potentially all those of African descent (Barickman, 1998; Gato, 2020). The distrust toward republicans were shared by many in the military, a trend reinforced by the fact that, in contrast with a mostly white officer corps, the majority of soldiers were afro-descendants (Beattie, 2001, pp. 155-156; McCann, 2009, p. 42). This was indicated in a series of soldiers' revolts that followed the coup and left traces for historians.

The establishment of the republic in the capital of Santa Catarina was assisted by infantry officers stationed there. On the night of November 17, while their commanders celebrated at the Republican Club, dozens of soldiers, led by a corporal, took to the streets, flying the imperial flag and hailing the emperor. The revolt was only quelled when their captain, who had been nominated chief of police, ordered customs and prison guards to fire at the "seditious" soldiers, killing and wounding some. Those captured were sent in chains to Rio de Janeiro. Roughly one month later, on December 20, when news of the coup reached the remote Paraguayan frontier in Mato Grosso, soldiers of an artillery battalion revolted, refusing to adhere to the republic "because they were freed on May 13 by princess Isabel." After the soldiers rebuffed their officers' commands, setting fire to their barracks, the revolt was finally suppressed, not without casualties. In describing the unsubordinated soldiers, a lieutenant declared that they were "assassins, capoeiras, rioters, thieves, and drunkards" (Castro, 2004).

Some of the same adjectives were also employed to describe the soldiers that two days earlier had revolted in the nation's capital, with more dire consequences. On December 18, soldiers of the $2^{\text {nd }}$ regiment of artillery, headquartered close to the old imperial palace, took the armory, hoisted the flag of the Empire, and marched on the streets cheering for the monarchy, later intrenching themselves on headquarters, where they "placed in battery all the artillery of the regiment." The government acted swiftly, sending troops to surround the building. The siege continued through to the next day, with several shots being fired, resulting in a number of deaths, estimated from three

${ }^{24}$ Diario de Noticias. Nov. 18, 1889. 
to dozens according to different sources. ${ }^{25}$ The soldiers' surrender was followed by an inquiry, in which some declared that their aim had been to defend the "godly" monarchy against the "cursed" republic (Castro, 2004).

The government's response was simultaneously dismissive and extreme. On the one hand, the pro-government press strove to depoliticize the "mutiny," attributing it to widespread indiscipline, drunkenness, and corruption by forces "foreign" to the military, highlighting that money of unknown origin had been found among the soldiers' possessions. ${ }^{26}$ On the other hand, the revolt was therefore treated as civilian in origin, having been the work of "enemies" of the regime who had enticed the soldiers. As the chief of police would recount years later, the government, lacking any significant evidence, decided to use the episode to make a sweeping show of force. ${ }^{27}$

In the immediate aftermath of the revolt, Ouro Preto and Silveira Martins, already imprisoned, were banished from Brazil. ${ }^{28}$ A number of prominent politicians, alongside some officers, were arrested for "questioning." Most of the civilians detained were Liberal, some were Conservative, but there was a noteworthy pattern: almost all of them had held, in the previous decade, one or both of the military ministries. ${ }^{29}$ Thus there were possibly concerns on alliances they could have forged within both forces.

On December 23, a decree imposed martial law in the country. Thenceforth, civilians were subject to military trials and penalties for sedition when suspect of bribing, enticing, or intoxicating soldiers or officers, turning them "against their duties to their superiors or to the republican system;" spreading in military ranks "false and subversive ideas" contrary to the republic; and advising or promoting "verbally, by writing, or by acts, civil revolt or military indiscipline." 30 The thin line between the "transgressions" listed and the basic exercise of free speech led to the termination of the main opposition newspaper, the Tribuna Liberal, founded by Ouro Preto's initiative in 1888 (Magalhães Júnior, 1957, pp. 115-117, v. 2). Although the government argued that the decree was not directed against the press, its discretionary character created a climate of uncertainty that would, in the following months, become widespread anxiety, after the shutdown of newspapers and the repeated arrests and threats against editors, journalists, and alleged "conspirators" throughout the country. ${ }^{31}$

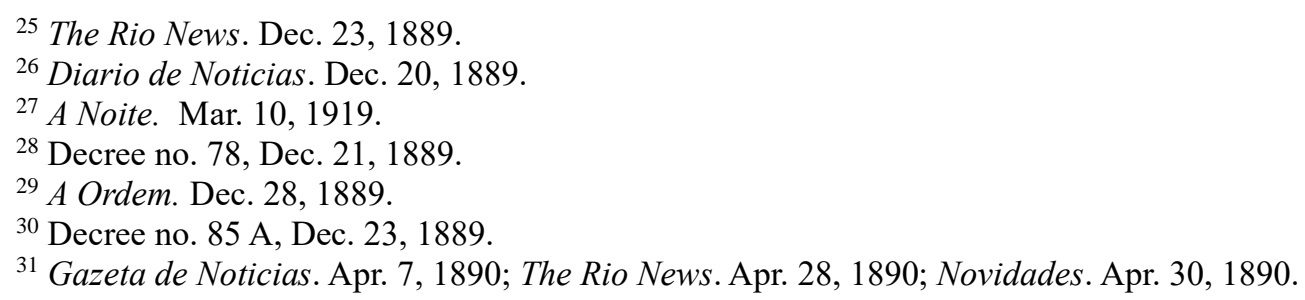


The press's hesitations were flagrant when, at the end of March, newspapers were reluctant to divulge what appears to have been another serious case of military sedition. The information available suggests that troops refused to embark to the south of the country, following attempts to impose discipline and reorganize the army. ${ }^{32}$ The government, fearful of the developments, apparently linked the acts of insubordination to a series of anonymous posters inciting rebellion against the "dictatorship" affixed on Rio's streets. The response was to subject to the "regimen" of the December decree any person suspect of originating or aiding the circulation, "through the press, by telegram, or in any other matter," of "false notices" and "alarming rumors," including "those referring to the discipline of military bodies, to the stability of institutions and to public order." 33 The government insisted that the analysis or discussion of its actions were exempt from the "generality" of the disposition. However, the distinction between information and rumor, under the prevailing layers of secrecy and misinformation, was far from clear, and the climate of insecurity for both the press and private citizens would not be abated. Parallel to this, it was clear that its evergrowing autocratic inclination betrayed the government's own anxieties.

The regime's distrust of its soldiers and fears for its own safety seem to have been key elements in the authoritarian degradation. The aforementioned growing deployment of army units to police the streets had been accompanied by the creation of an "academic battalion," composed of students of civil colleges, as well as of the Students' Corps of the Military School, both commanded by officers reporting directly to the War Ministry. ${ }^{34}$ Ideally kept under the authority of the minister of justice, the police's continuous expansion and militarization (including the appointment of army officers as commanders) soon created a jurisdictional grey area between the ministers of justice, war, and the generalissimo himself. ${ }^{35}$ In any case, the targets of the broad activities of the expanded police forces were mainly civilians.

This was clear in the case of the "disorderly" capoeiras, in the weeks following the coup. Originated in colonial times as a martial art practiced by slaves, capoeira gradually became a common feature of urban areas throughout the nineteenth century. Mainly afro-descendants, those practicing capoeira were sometimes members of "gangs" that conducted "deadly street rumbles," but also became an "integral part of urban political life in the late empire," having direct links to the Liberal and Conservative parties and serving as "informal security forces" at polling stations and political meetings. Moreover, a good number of them were army and navy praças (Beattie, 2001, pp.

\footnotetext{
32 The Rio News. Mar. 31, 1890; A Provincia. Apr. 9, 1890.

${ }^{33}$ Decree no. 295, Mar. 29, 1890.

${ }^{34}$ Decree no. 42, Dec. 6, 1889; Decree no. 242, Mar. 4, 1890.

${ }^{35}$ Decree no. 155, Jan. 14, 1890; Decree no. 342, Apr. 19, 1890; Decree no. 852, Oct. 13, 1890.
} 
145-146). Following the abolition of slavery, the displacement of thousands of former slaves, many of whom migrated to Rio and other cities, created a sense of widespread insecurity among certain sectors of society, with the capoeiras (and the ensuing expansion of their maltas and activities, some of which directed against republican organizations and meetings) becoming preferred vessels for such fears (Bretas, 1991).

In mid-December 1889, a pro-government newspaper celebrated the fact that Rio's chief of police, unincumbered by former legal and judicial constraints, could proceed to finally liberate the city from the "horde of vandals that hovered over the Brazilian communion." 36 In the subsequent months, an undetermined but substantial number of men, even if only suspected of having links to capoeiragem, were summarily arrested and mostly banished to the penal settlement located in the northern archipelago of Fernando de Noronha. It appears that another destiny was the ranks of the army. In this regard, it is of note that, in early January, a steamer destined for Mato Grosso departed from Rio with 56 men of the $2^{\text {nd }}$ regiment of artillery and 43 capoeiras aboard. According to the press, it was not stated whether "the latter have been enlisted in the army." 37 This was not an isolated case.

Following the November 20 decree giving governors extensive powers over the states' security apparatuses, the transformations of police forces in both size and scope were swift. ${ }^{38}$ Still in November, a Conservative newspaper from Pernambuco lauded the provisional government for appointing army officers to command the "police corps", stating that they should have a complete "military organization." In December, the same newspaper praised the state's military governor and the republican chief of police for their resolve in eliminating the "elements of disorder" that in the monarchy's last moments had wrought grievous disturbances upon "public order." 39 Countering the previous "laxity," the new order's fundamental engine was a militarized and expanded state police force, whose main task (as was clear in the chief of police's circulars) was to imprison and deport "vagabonds." 40

Significantly, in April, the subsequent governor (another army officer) revealed his intentions to send all of Pernambuco's "disorderly characters and anarchists" on a gunboat to Fernando de Noronha. ${ }^{41}$ From São Paulo, dozens of "convicts" would have the same destiny weeks later. ${ }^{42}$ In fact, the recourse seems to have been so widely employed that in July the minister of justice admonished

\footnotetext{
${ }^{36}$ Novidades. Dec. 12, 1889.

${ }^{37}$ The Rio News. Jan. 6, 1890.

${ }^{38}$ Decree no. 7, Nov. 20, 1889.

${ }^{39}$ A Epocha. Nov. 29 and Dec. 18, 1889.

${ }^{40}$ Jornal do Recife. Feb. 22, 1890.

${ }^{41}$ The Rio News. Apr. 28, 1890.

${ }^{42}$ The Rio News. June 2, 1890.
} 
a governor that the penal settlement, with an exploding population already in the thousands, "cannot possibly hold all the incorrigibles the various state governors want sent there." 43 If the archipelago was not always a viable destination, impressment was an alternative. In August, it was reported that the war minister had "declined to accept 52 incorrigible vagabonds sent here from Sergipe," since he already had "enough vagabonds in the ranks." 44

In other states, this trend was initiated very early on. In Maranhão, following the massacre of the libertos, the governing junta formed a "corps of 200 volunteers," led by an army captain to police the capital. ${ }^{45}$ In Ceará, one of the first acts of Lieutenant Colonel Ferraz as governor was the creation of the republican military brigade, commanded by an army officer and composed of students of the Military School, navy apprentices, artillery and infantry soldiers, and police praças. ${ }^{46}$ In December, the Viscount of Pelotas completely reorganized the Rio Grande do Sul police, giving it full military status and hierarchy. ${ }^{47}$ In São Paulo, the police was so quickly expanded and militarized that in a few years it would resemble a "small army." In Minas Gerais, a newspaper (significantly called $A$ Ordem) complimented the expediency of the augmented police forces in fighting "idleness" and "vagrancy" (Maia, 2001; Karnikowski, 2010; Rosemberg, 2012; Viscardi, 1995). ${ }^{48}$

The impressment, imprisonment, deportation, and massacre of "vagabonds" and "disorderly" elements thus exposed which members of society would be predominantly targeted as foes of the new "order". The reach of state violence unleashed in the context surveyed here can only be thoroughly understood in view of two correlated phenomena. First, the racial undertones in the adjectives indistinctively employed in reference to libertos, capoeiras, and rebelled praças are palpable. They were part of a broader trend, since the final years of slavery, in which the uncertainties and conflicting expectations regarding the role of former slaves in society and their rights as Brazilian citizens raised deep anxieties. In this context, the libertos (and soon by extension those of African descent) were increasingly painted as threats to public order and safety and as inherently unprepared for citizenship (Azevedo, 2004; Schwarcz, 2017). However, the unconditional law of abolition hindered the imposition of formal restrictions (such as the obligation to find employment) on their constitutionally granted rights as citizens. The resentment generated by imperial institutions' alleged impotence or active refusal to subject this mass of citizens to an exceptional regime was analogous to the acrimony directed, especially in the rural areas of the South, against

\footnotetext{
${ }^{43}$ The Rio News. Jul. 7, 1890.

${ }^{44}$ The Rio News. Aug. 11, 1890.

${ }^{45}$ Gazeta do Norte. Dec. 3, 1889.

${ }^{46}$ Gazeta do Norte. Nov. 20, 1889.

${ }^{47}$ A Federação. Dec. 26, 1889.

${ }^{48}$ A Ordem. Feb. 24, 1890.
} 
magistrates and other state authorities whose mission was to enforce emancipationist policies and who often espoused abolitionist beliefs (Pirola, 2018, pp. 472-474).

If there was considerable "ambiguity" as to how the imperial state dealt with the citizenship of former slaves and those that had been born free, there also was, in the late Empire, a growing recognition of their rights, accompanied by a gradual expansion, in size and scope, of the institutions directly responsible for enforcing those rights, particularly the judiciary, often sought out by the most vulnerable as a legitimate instance for the resolution of conflicts (Mattos, 1998; Koerner, 1998; Azevedo, 2010; Mamigonian, 2011). This was accompanied by a consensus, among significant segments of the political elite, that after abolition the nefarious legacy of slavery still imposed a major challenge on the whole country (Ribeiro, 2015). The breakup of this contention was a fundamental feature of the self-legitimizing discourse advanced by many (civilian and military) republicans, which associated slavery with monarchy, alleging that the mere overthrow of the latter had freed the country from the effects of the former. Thus, secondly, if institutions shared no responsibility, all the shortcomings associated with centuries of bondage could be individualized. The sole task of the state was therefore to protect society from such deleterious influence.

It is significant, in this regard, that the civilian ministers of justice, agriculture, and the interior, throughout 1890, were direct representatives of southern areas where slave interests were formerly paramount and where anxieties regarding abolition and its consequences assumed virulent forms. ${ }^{49}$ But the prevalence of their priorities was only possible due to the institutional vacuum in which government officials acted, following the dissolution of parliament, provincial assemblies, municipal councils, and the disarray of the judiciary. The scale of power accumulated by the national and state executives and the hurry in consolidating the regime therefore help to explain the rapid militarization of political life. However, the hastened attempts to impose republican "order" and suppress or co-opt opposition, alongside the armed forces' deep politicization, created such an unstable and divisive situation that the government's own viability soon came into question.

\section{Politics and dictatorship}

Alongside control over police forces, the November 20 decree gave governors discretionary authority concerning most subjects. However, despite their significant powers (and the fact that over half of the governors nominated during the first weeks of the republic were officers), their position was far from secure. On the one hand, the provisional government could to some degree dispose of

\footnotetext{
${ }^{49}$ Respectively, the paulistas Manuel Ferraz de Campos Sales and Francisco Glicério Cerqueira Leite, and the mineiro José Cesário de Faria Alvim.
} 
governors unilaterally; on the other hand, the states' political instability meant that governors had the often-impossible task of avoiding the escalation of conflicts, while favoring allies and suppressing or co-opting opposition. Moreover, the emergence of new political protagonists gave rise to diffuse demands, making the production of compromises more challenging.

Therefore, in addition to (and as inevitable consequences of) the challenges to military hierarchy, the arbitrary nature of military rule, and the politicization of the barracks, three complementary elements of the militarization of politics in the early republic will be addressed in this final section. First, while making the competition for political favor more unruly and ferocious, the disarray of traditional political parties - which provided corridors to the officers' political ambitions while securing their loyalty to civilian leadership and institutions -, in a context of military rule, often made officers the arbiters of partisan rivalries. Secondly, given the governors' own political preferences or inability, disagreements caused by their policies in the already politicized barracks could be exploited by oppositionists. The growing factionalism in the armed forces was thus another consequential element of the militarization of politics.

The militarized states of Ceará and Rio Grande do Sul offer contrasting and complementary evidence. In Ceará, the virtual non-existence of an organized republican movement gave the officers that took over power following the coup d'état substantial room for political maneuver. Loeitenant Colonel Ferraz, upon assuming government, did not waste time in suppressing attempts by civilian politicians to rearticulate and organize an alternative to military rule. Ferraz's grip on power seems to have been solid enough in the first moments of the republic to both reject initiatives from the provisional government to replace him and, in the ensuing months, promote the rearticulation of political forces. ${ }^{50}$

In Rio Grande do Sul, despite his prestige, Pelotas's government did not even last three months. The general's attempts to adopt a conciliatory stand, integrating the Liberal gasparistas, his past allies led by the exiled Silveira Martins, into the administration were deeply resented by the state's "historical" Republican Party, whose members, led by Júlio de Castilhos, occupied newly created bureaucratic posts around the governor. The castilhistas understood that, given their scarce numbers, their grip on power depended on breaking the preeminence of Liberals in the state. They also knew that this could only be accomplished with support from the military and from Deodoro, who deeply distrusted the gasparistas. Thus the castilhistas, intending to explore divisions in the army

\footnotetext{
${ }^{50}$ Gazeta do Norte. Nov. 27 and Dec. 3, 1889.
} 
in order to ostracize officers suspected of Liberal sympathies, soon abandoned their posts and fiercely denounced Pelotas for his political associations (Love, 1971, pp. 38-41).51

The Republicans' attempts to use the army's politicization in their favor succeeded when certain officers declared that their support for Pelotas depended on him cutting ties with gasparistas. ${ }^{52}$ The viscount's subsequent renunciation, in mid-February, indicates that he was not capable of exerting authority over a factionalized army. This situation created a dilemma for both the provisional government and the castilhistas. To Deodoro and his ministers, it was clear that the Republicans' radicalism and carelessness made them untrustworthy allies. To Republicans, it was inevitable to recognize that, despite their sole claim to legitimacy, they lacked the political strength to unilaterally establish and consolidate their hold on power. The lack of alternatives made both sides reach an uneasy agreement, which consisted of leaving a high-ranking military officer (ideally capable of containing the barracks) as head of the executive, while giving castilhistas control over the state's bureaucracy and treasury, both essential to the extension of their influence.

In Ceará, Rio Grande do Sul, and elsewhere, the full-scale effects of these uneasy arrangements were unveiled when electoral considerations gained prominence. According to a decree published on December 21, elections to the Constituent Congress (to be convened on the republic's first anniversary) were set for September 15, 1890. Two other decrees in February and June gave shape to the new electoral system, respectively regulating electoral enrolment and the general process. ${ }^{53}$ As a whole, the system gave immense powers to governors. First and foremost, it attributed a central role, from enrolment to vote counting, to municipal intendências, which, differently from the abolished elective municipal councils (câmaras municipais), were appointed by governors and could be replaced at their discretion..$^{54}$ The adopted system, which was based on an open list of candidates of which voters were to choose as many names as the state's representation in Congress, encouraged the formation of chapas oficiais, i.e., lists of candidates sympathetic to (and supported by) the government. The regulations also extinguished former electoral incompatibilities, allowing ministers, governors, chiefs of police, officers on active duty, and government officials to run. Parallel to this, praças were excluded from voting.

The opposition was aware that the system imposed almost insurmountable obstacles to the election of alternative chapas or independent candidates. Thus, in most states, attempts to combine non-aligned candidates into a single list failed, and oppositionists tended to abstain en masse. This

\footnotetext{
${ }^{51}$ A Federação. Feb. 13, 1890; Gazeta de Noticias. Mar. 5, 1890.

${ }^{52}$ Jornal do Recife. Feb. 27, 1890.

${ }^{53}$ Decree no. 78 B, Dec. 21, 1889; Decree no. 200 A, Feb. 8, 1890; Decree no. 511, June 23, 1890.

${ }^{54}$ Decree no. 50 A, Dec. 7, 1889; Decree no. 107, Dec. 30, 1889.
} 
was the case, e.g., of the "national party" of Bahia and of the "moderate party" of Rio de Janeiro. ${ }^{55}$ In Ceará, where the military government drafted a chapa composed of aligned civilians and officers, the marginalized Liberal opposition, led by former minister of war Antônio Joaquim Rodrigues Junior, publicly denounced voter suppression and tried to stage a protest in the state capital on the eve of the election. The troops' intervention led to casualties and to the arrest of many oppositionists, with Rodrigues Junior being confined aboard a ship. ${ }^{56}$

In Rio Grande do Sul, the National Union - a coalition of Liberal gasparistas, some Conservatives, and disgruntled military officers led by the Viscount of Pelotas - was formed in June, presenting a chapa to the electorate and stating as its goal the reversal of several government policies. The castilhistas, surrounding General Cândido José da Costa (governor since May), responded by rebranding themselves as the Republican Union and presenting an official list of candidates that included prestigious officers. The strength of the National Union, composed of still influent politicians, led to a growing government campaign of intimidation, that involved voter suppression and the imprisonment of local leaderships. It wasn't, however, until officers stationed in the state threatened to intervene to guarantee the victory of pro-government candidates that the National Union announced it would abstain from the ballot (Magalhães Júnior, 1957, p. 213, v. 2). ${ }^{57}$

In other states, the newly formed military clubs had few scruples in directly intervening in the electoral process as a whole. In the crucial State of Bahia, military interference complicated an already unstable political situation. Amid constant changes in the pro-government chapa to appease different groups, a last-minute push from the military club to replace certain civilian candidates with officers ended up prompting such scandalous frauds in the vote counting that the state would be granted the inglorious distinction of the first annulment of an election under the republic. 58

These threats and interferences not only compromised the system's already questionable legitimacy, but also created uneasiness in the military ranks. Rear Admiral Custódio de Melo, for example, refused the candidacy offered by the Bahian military club on the basis that official candidates should not exist. ${ }^{59}$ In Rio Grande do Sul, some officers published open letters reminding comrades that the role of the armed forces did not involve voter suppression. ${ }^{60}$ Even the more aligned officers could be candid in their criticisms of the provisional government's policies. Close to the election, navy minister Wandelkolk, a Senate candidate, gave an interview to a Rio newspaper

\footnotetext{
55 Pequeno Jornal. Jul. 25 and 26, 1890; Gazeta de Noticias. Sept. 4, 1890.

${ }^{56}$ Jornal do Recife. Sept. 19 and 27, 1890.

${ }^{57}$ Correio Paulistano. Aug. 23, 1890; A Tribuna. Sept. 9, 1890.

${ }^{58}$ Annaes do Congresso Constituinte da Republica. Camara dos Srs. Deputados. Nov. 9, 10, 11, 12, and 18, 1890.

${ }^{59}$ Pequeno Jornal. Aug. 23, 1890.

${ }^{60}$ A Tribuna. Sept. 9 and 10, 1890.
} 
lambasting the record of the finance minister, Ruy Barbosa, and other policies. ${ }^{61}$ Lower-ranking officers followed suit, among them the navy lieutenant (and first director of Rio's telegraph office under the republic), José Augusto Vinhais. As a candidate for deputy in the capital's pro-government list, Vinhais defended the return of exiled imperial politicians, such as Ouro Preto and Silveira Martins, to the political arena. ${ }^{62}$

It was probably the recognition of these divisions (and the eagerness to explore them) that had prompted, in July, the reinauguration of the Tribuna Liberal, renamed A Tribuna, as an openly oppositionist newspaper in the capital. In the following months, the newspaper would viciously attack the government's corruption, incompetence, and authoritarianism, while denouncing voter suppression and lauding opposition candidates. Promoting the antagonism between Deodoro and Silveira Martins, as symbols of the contrasting paths the republic could follow, A Tribuna explored the generalissimo's record of nurturing his family's ambitions, having brothers and nephews (all officers) as state governors and candidates for Congress, while highlighting his (military and administrative) shortcomings (Magalhães Júnior, 1957, pp. 238-240, v. 2).

Reporting directly to Ouro Preto, A Tribuna's chief editor, Antônio de Medeiros, acknowledged that the newspaper's continuous publication, despite repeated threats, was significantly due to discontent in the government's own ranks. The rivalry between army and navy was particularly noted. In April, the adjutant-general of the army, Floriano Peixoto, had replaced Benjamin Constant, whose inability to impose discipline deeply bothered Deodoro, as minister of war (Magalhães Júnior, 1957, pp. 197-198, v. 2). In August, the politically savvy Peixoto gained influence enough to become vice-chief of the provisional government. Blindsiding Wandenkolk, the move reinforced the dissatisfaction of navy officers, whose secondary role vis-à-vis the army was resented. ${ }^{63}$ It was in this context that Wandenkolk set up a meeting with Medeiros to (according to the latter's account) express his wishes for the return of Ouro Preto in order to "save" the country's finances. Parallel to this, Medeiros reported that some army officers had been approaching him sympathetically, even offering troops to protect A Tribuna from reprisals (Medeiros, 1890).

It is possible that Medeiros' accounts were exaggerated. He was, however, far from isolated in pointing to the growing unrest in military ranks and to the rifts between both forces. The destruction, two weeks after the republic's first anniversary, of his newspaper's headquarters by a mob of army officers led by one of Deodoro's nephews, with the generalissimo's tacit consent, indicated that the brazen (and indirect) recourse to force was the last resort of a weakened government. The fierce

\footnotetext{
${ }^{61}$ Gazeta de Noticias. Sept. 7, 1890.

${ }^{62}$ Gazeta de Noticias. Sept. 14, 1890.

${ }^{63}$ Pequeno Jornal. Sept. 2, 1890.
} 
reactions of Wandenkolk and other navy officers, asking for those responsible to be severely punished, indicate that the split was irreversible (Abranches, 1998, p. 284-288; Magalhães Júnior, 1957, pp. 240-257, v. 2). The prophetic discussion, in the press and elsewhere, of an oncoming civil war, suggest that the country was growing accustomed to the endemic instability and well on the path of coups, countercoups, and military conflicts that would become its everyday reality in the following years. This profound instability, feeding a deep crisis of legitimacy, and the breakdown of state authority in much of the country could be at the core of a swift rise of private violence in the regime's first decades (Vellasco, Andrade, 2018). A course perhaps inevitable since the violent imposition of military rule on November 15, 1889.

\section{Bibliography}

\section{Primary sources}

\section{Official documents}

Legislation - $\underline{\text { https://www2.camara.leg.br/atividade-legislativa/legislacao/colecao-anual-de-leis }}$

Brasil. 1889. Decretos do Governo Provisorio da Republica dos Estados Unidos do Brazil. Rio de Janeiro: Imprensa Nacional.

Brasil. 1890. Decretos do Governo Provisorio da Republica dos Estados Unidos do Brazil. Rio de Janeiro: Imprensa Nacional.

Constituent Congress - $\underline{\text { https://www.senado.leg.br/publicacoes/anais/asp/RP AnaisRepublica.asp }}$

Brasil. 1924. Annaes do Congresso Constituinte da Republica. $2^{\text {nd }}$ rev. ed. Rio de Janeiro: Imprensa Nacional.

\section{Manuscript}

\section{Arquivo do Instituto Histórico e Geográfico Brasileiro (IHGB)}

Medeiros, Antonio de. 1890. Letters addressed to Afonso Celso de Assis Figueiredo, Visconde de Ouro Preto. AIHGB. Col. Ouro Preto, DL 427.29, 6 docs.

\section{Newspapers}

Hemeroteca Digital/Biblioteca Nacional - http://bndigital.bn.gov.br/hemeroteca-digital/

A Epocha

A Federação

A Ordem

A Provincia

B RASILIANA: Journal for Brazilian Studies. Vol. 10, No. 2, 2021. ISSN 224.5-4373. 


\author{
A Noite \\ A Tribuna \\ Correio Paulistano \\ Diario da Bahia \\ Diario de Noticias \\ Gazeta de Noticias \\ Gazeta do Norte \\ Jornal do Recife \\ Novidades \\ Pacotilha \\ Pequeno Jornal \\ The Rio News
}

\title{
$\underline{\text { Printed }}$
}

Abranches, Dunshee de. 1998. Actas e actos do governo provisorio. Brasília: Senado Federal.

Aragão, Antonio Ferraz Moniz de. 1923. A Bahia e os seus governadores na República. Bahia: Imprensa Oficial do Estado.

Campos Sales, Manuel Ferraz de. 1983. Da propaganda à presidência. Brasília: Editora Universidade de Brasília.

Vianna, Antonio Ferreira. 1896. O antigo regimen. Rio de Janeiro: Cunha \& Irmão. Available at https://www2.senado.leg.br/bdsf/handle/id/242454

\section{Secondary sources}

Abreu, Alzira Alves de (ed.). 2015. Dicionário histórico-biográfico da Primeira República (1889-1930). Rio de Janeiro: CPDOC/FGV.

Arendt, Hannah. 1961. Between past and future. Six exercises in political thought. New York: The Viking Press.

Arias Neto, José Miguel. 2001. Em busca da cidadania: praças da Armada Nacional, 1867-1910. Doctoral thesis, Universidade de São Paulo, São Paulo, SP.

Azevedo. Célia Maria Marinho de. 2004. Onda Negra, medo branco: o negro no imaginário das elites, século XIX. $2^{\text {nd }}$ ed. São Paulo: Annablume.

Azevedo, Elciene. 2010. O direito dos escravos: lutas jurídicas e abolicionismo na província de São Paulo. Campinas, SP: Ed. Unicamp.

Barickman, B. J. 1998. Até a véspera: o trabalho escravo e a produção de açúcar no recôncavo baiano (18501881). Afro-Ásia, v. 21-22, pp. 177-238. Available at https://doi.org/10.9771/aa.v0i21-22.20967

Beattie, Peter M. 2001. The tribute of blood: army, honor, race, and nation in Brazil, 1864-1945. Durham, NC: Duke University Press.

Bretas, Marcos Luiz. 1991. A queda do Império da navalha e da rasteira (a República e os capoeiras). Estudos Afro-Asiáticos, 20, pp. 239-255.

Cardoso, Fernando Henrique. 1975. Dos governos militares a Prudente - Campos Sales. In: FAUSTO, Bóris.

S RASILIANA: Journal for Brazilian Studies. Vol. 10, No. 2, 2021. ISSN 2245-4373. 
História Geral da Civilização Brasileira. T. III: O Brasil Republicano, v. 1: Estrutura de poder e economia. São Paulo: DIFEL, pp. 13-50.

Carone, Edgard. 1983. A República Velha. Evolução Política (1889-1930). $4^{\text {th }}$ ed. São Paulo : DIFEL.

Carvalho, José Murilo de. 2003. A construção da ordem: a elite política imperial. Teatro de sombras: a política imperial. $4^{\text {th }}$ ed. Rio de Janeiro: Civilização Brasileira.

Carvalho, José Murilo de. 2006. Forças Armadas e política no Brasil. $2^{\text {nd }}$ ed. Rio de Janeiro: Jorge Zahar.

Castro, Celso. 1995. Os militares e a República: um estudo sobre cultura e ação política. Rio de Janeiro: Jorge Zahar.

Castro, Celso. 2004. Revoltas de soldados contra a República. In: CASTRO, Celso; IZECKSOHN, Vítor; KRAAY, Hendrik (ed.). Nova História Militar Brasileira. Rio de Janeiro: FGV; Bom Texto, 2004, pp. 301-313.

Costa, Emília Viotti da. 1985. Da Monarquia à República: momentos decisivos. $3^{\text {rd }}$ ed. São Paulo: Brasiliense.

Costa, Wilma Peres. 1996. A espada de Dâmocles: o Exército, a Guerra do Paraguai e a crise do Império. São Paulo: Editora Hucitec/Editora da Unicamp.

Dantas, Monica Duarte. 2011. Epílogo. Homens livres pobres e libertos e o aprendizado da política no Império. In: Id. (ed.). Revoltas, motins, revoluções: homens livres pobres e libertos no Brasil do século XIX. São Paulo: Alameda.

Dolhnikoff, Miriam. 2005. O pacto imperial: origens do federalismo no Brasil. São Paulo: Globo.

Dudley, William S. 1976. Professionalization and politicization as motivational factors in the Brazilian Army coup of 15 November 1889. Journal of Latin American Studies 8, I, pp. 101-125. Available at https://www.jstor.org/stable/156206

Ferraz, Sérgio Eduardo. 2012. O Império revisitado. Instabilidade ministerial, Câmara dos Deputados e Poder Moderador (1840-1889). Doctoral thesis, Universidade de São Paulo, São Paulo, SP. Available at https://www.teses.usp.br/teses/disponiveis/8/8131/tde-20122012-122802/pt-br.php

Gato, Matheus. 2020. O massacre dos libertos: sobre raça e república no Brasil (1888-1889). São Paulo: Perspectiva.

Graham, Sandra Lauderdale. 2011. O Motim do Vintém e a cultura política do Rio de Janeiro, 1880. In: DANTAS, Monica Duarte (ed.). Revoltas, motins, revoluções: homens livres pobres e libertos no Brasil do século XIX. São Paulo: Alameda pp. 485-510.

Holanda, Sérgio Buarque de. 1977. História Geral da Civilização Brasileira. T. 2: O Brasil Monárquico. V. 5: Do Império à República. $2^{\text {nd }}$ ed. São Paulo: DIFEL, 1977.

Karnikowski, Romeu Machado. 2010. De exército estadual a polícia militar: o papel dos oficiais na policialização da Brigada Militar (1892-1988). Doctoral thesis, Universidade Federal do Rio Grande do Sul, Porto Alegre, RS.

Koerner, Andrei. 1998. Judiciário e cidadania na constituição da República Brasileira. São Paulo: Hucitec / Departamento de Ciência Política, USP.

Love, Joseph L. 1971. Rio Grande do Sul and Brazilian regionalism, 1882-1930. Stanford, CA: Stanford University Press.

Lynch, Christian Edward Cyril. 2018. Necessidade, contingência e contrafactualidade. A queda do Império 
Ribeiro, Filipe Nicoletti. The rule of force: militarism and the militarization of politics in the early Brazilian republic (1889-1890).

reconsiderada. Topoi, Rio de Janeiro, v. 19, no. 38, pp. 190-216. Available at https://doi.org/10.1590/2237$\underline{101 \times 01903808}$

Magalhães Júnior, Raimundo. 1957. Deodoro: a espada contra o Império. São Paulo: Companhia Editora Nacional, 2. v.

Maia, Clarissa Nunes. 2001. Policiados: controle e disciplina das classes populares na cidade do Recife, 18651915. Doctoral thesis, Universidade Federal de Pernambuco, Recife, PE.

Mamigonian, Beatriz Galloti. 2011. O Estado nacional e a instabilidade da propriedade escrava: a lei de 1831 e a matrícula dos escravos de 1872. Almanack, no. 2, pp. 20-37. Available at https://doi.org/10.1590/2236$\underline{463320110203}$

Mattos, Hebe Maria. 1998. Das cores do silêncio: os significados da liberdade no sudeste escravista. Rio de Janeiro: Nova Fronteira.

Mattos, Ilmar Rohloff de. 1987. O tempo Saquarema. São Paulo: Hucitec.

Mccann, Frank D. 2009. Soldados da pátria: história do Exército Brasileiro, 1889-1937. São Paulo: Companhia das Letras.

Morgan, Zachary. 2003. The revolt of the lash. In: BELL, Christopher M.; ELLEMAN, Bruce A. Naval mutinies of the twentieth century: an international perspective. London; Portland, OR: Frank Cass.

Pirola, Ricardo Figueiredo. 2018. A lei de Lynch no ocaso da escravidão: linchamentos, justiça e polícia (18781888. In: OSÓRIO, Helen; XAVIER, Regina Célia Lima (ed.). Do tráfico ao pós-abolição: trabalho compulsório e livre e a luta por direitos sociais no Brasil. São Leopoldo, RS: Oikos, pp. 454-480.

Ribeiro, Filipe Nicoletti. 2015. Império das incertezas: política e partidos nas décadas finais da monarquia brasileira (1868-1889). Master's dissertation, Universidade de São Paulo, São Paulo, SP. Available at https://www.teses.usp.br/teses/disponiveis/8/8138/tde-11122015-142218/pt-br.php

Rosemberg, André. 2012. Prelúdio de um 'pequeno exército'? A força policial paulista nos primeiros anos da República (1890-1895). História Unisinos. 16(3), pp. 333-345. Available at http://revistas.unisinos.br/index.php/historia/article/view/htu.2012.163.06

Schulz, John. 1994. O Exército na política: origens da intervenção militar. São Paulo: Edusp.

Schwarcz, Lilia Moritz. 2017. Retrato em branco e negro: jornais, escravos e cidadãos em São Paulo no final do século XIX. São Paulo: Companhia das Letras.

Vargas, Jonas Moreira. 2007. Entre a paróquia e a Corte: uma análise da elite política do Rio Grande do Sul (18681889). Master's dissertation, Universidade Federal do Rio Grande do Sul, Porto Alegre, RS. Available at http://hdl.handle.net/10183/13085

Vellasco, Ivan \& ANDRADE, Cristiana Viegas. 2018. Criminalidade, violência e justiça na vila de Tamanduá. A reconstrução de estatísticas criminais do Império à República. Varia Historia, v. 34, no. 64, pp. 51-80. Available at https://doi.org/10.1590/0104-87752018000100003

Viscardi, Cláudia Maria Ribeiro. 1995. A Força Pública em Minas Gerais na Primeira República. Locus: Revista de História, 1(1), pp. 41-61. Available at https://periodicos.ufjf.br/index.php/locus/article/view/20401 